\title{
Hydrogen Embrittlement of Biomedical Shape Memory Ni-Ti Wire
}

Jan Serak, Dalibor Vojtech, Vojtech Hybasek, Alexandra Senkova, Jiri Kubasek, Alena Michalcova, Iva Pospisilova, Fousova Michaela

Department of Metals and Corrosion Engineering, University of Chemistry and Technology Prague. Technicka 5, 16628 Prague 6. Czech Republic. E-mail: serakj@vscht.cz

Equimolar NiTi alloy known as Nitinol, is a modern metallic material on which very high demands are placed. This alloy has been used for its unique properties, such as shape memory, superelasticity and pseudoplasticity. Nitinol also has very good corrosion resistance and applicability as a biomaterial. In medicine Nitinol is most often used in the form of stents, which are used as reinforcement bottlenecks in the cardiovascular system or gastrointestinal tract, ortodontistic wires, orthopedic terminals of micro invasive surgery tools, tools for endoscopy and apertures or aneurysms. Successful use is subject to a manufacturer's declared stable mechanical properties of Nitinol. These properties can significantly influence a hydrogen deposited in the alloy, both due to the manufacturing process itself so that the resulting exposure in the environment. It was shown that even very low contents of hydrogen in the alloy leading to a substantial reduction in plasticity and strength of Nitinol which may be one of the main causes of premature failure of medical implants in the specific environment of the human body.

Keywords: NiTi, Hydrogen, Mechanical Properties, Microstructure, Biomaterials

\section{Acknowledgement}

Research on Ni-Ti alloys was financially supported by the Czech Science Foundation (project no. P108/12/G043) and by support from specific university research (project MSMT No 20-SVV/2016).

\section{References}

[1] VOJTECH, D., KUBASEK, J., NOVAK, P. (2013). Corrosion properties of the superelastic shape memory Ni-Ti alloy for medical implants. In: Manufacturing Technology, Vol. 13, No.3, pp. 409-414, ISSN 1213-2489

[2] MOITRA, A., SOLANKI, K., HORSTEMEIER, M.F. (2011). The location of atomic hydrogen in NiTi alloy: A first principles study. In: Computational Materials Science, Vol. 50, pp. 820-823

[3] NOVAK, P., KRISTIANOVA, E., VAlAliK, M., DARME, C., SALVETR, P. (2015). New composite materials based on NiTi. In: Manufacturing Technology, Vol. 15, No. 4, pp. 644-647, ISSN: 1213-2489

[4] NOVAK, P., SKOLAKOVA, A., VOJTECH, V., KNAISLOVA, A., POKORNY, P., MORAVEC, H., KOPECEK, J., KUBATIK, T.F. (2014). Application of microscopy and X-ray Diffraction in optimization of the production of NiTi alloy by powder metallurgy. In: Manufacturing Technology, Vol. 14, No. 3, pp. 387-392, ISSN: 1213-2489

[5] ELAHINIA, M.H., HASHEMI, M., TABESH, M., BHADURI, S.B. (2012). Manufacturing and processing of NiTi implants: A review. In: Progress in Materials Science, Vol. 57, No. 5, pp. 911-946

[6] SERAK, J., VODEROVA, M., VOJTECH, D., NOVAK, P. (2014). Microstructure and Properties of Magnesium Aloys Working at Elevated Temperatures. In: Manufacturing Technology, Vol. 14, No.2, pp. 238-244, ISSN 12132489

[7] ROBERTSON, S.W., PELTON, A.R., RITCHIE, R.O. (2012). Mechanical fatique and fracture of Nitinol. In: International Materials Reviews, Vol. 57, No.1, pp. 1-36 